\title{
Clinical characteristics, activity levels and mental health problems in children with Long COVID: a survey of $\mathbf{5 1 0}$ children
}

Danilo Buonsenso, MD, Department of Woman and Child Health and Public Health, Fondazione Policlinico Universitario A. Gemelli IRCCS, Rome, Italy

Ferran Espuny Pujol, PhD, Clinical Operational Research Unit, University College London, London, UK

Daniel Munblit, PhD, Department of Paediatrics and Paediatric Infectious Diseases, Institute of Child's Health, Sechenov First Moscow State Medical University (Sechenov University), Moscow, Russia

Sammie Mcfarland, Founder of Long COVID Kids, UK

Frances K Simpson, MSc, Coventry University Group and Long COVID Kids, UK

\section{Corresponding authors}

Sammie Mcfarland, smcfarland@longcovidkids.org

Frances K Simpson

fsimpson@longcovidkids.org

CU Scarborough

Ashburn Road

Off Valley Road

Scarborough

Y011 2JW

\section{Abstract \\ Background}

The World Health Organization has recently recognized Long COVID, calling the international medical community to strengthen research and comprehensive care of patients with this condition. However, if Long COVID pertains to children as well is not yet clear.

\section{Methods}

An anonymous, online survey was developed by an organization of parents of children suffering from persisting symptoms since initial infection. Parents were asked to report signs 
and symptoms, physical activity and mental health issues. Only children with symptoms persisting for more than four weeks were included.

\section{Results}

510 children were included (56.3\% females) infected between January 2020 and January 2021. At their initial COVID-19 infection, 22 (4.3\%) children were hospitalized. Overall, children had persisting COVID-19 for a mean of 8.2 months (SD 3.9). Most frequent symptoms were: Tiredness and weakness (444 patients, $87.1 \%$ of sample), Fatigue (410, 80.4\%), Headache (401, 78.6\%), Abdominal pain (387, 75.9\%), Muscle and joint pain (309, 60.6\%), Post-exertional malaise (274, 53.7\%), rash (267, 52.4\%). 484 (94.9\%) children had had at least four symptoms. 129 (25.3\%) children have suffered constant COVID-19 infection symptoms, 252 (49.4\%) have had periods of apparent recovery and then symptoms returning, and 97 (19.0\%) had a prolonged period of wellness followed by symptoms. Only $51(10.0 \%)$ children have returned to previous levels of physical activity. Parents reported a significant prevalence of Neuropsychiatric symptoms.

\section{Conclusions}

Our study provides further evidence on Long COVID in children. Symptoms like fatigue, headache, muscle and joint pain, rashes and heart palpitations, and mental health issues like lack of concentration and short memory problems, were particularly frequent and confirm previous observations, suggesting that they may characterize this condition. A better comprehension of Long COVID is urgently needed.

Keywords: long covid; children; SARS-CoV-2 


\section{Background}

One year after the first description of SARS-COV-2 in China, several results have been achieved in the understanding of epidemiology and physio-pathological bases of COVID-19 (1) and its treatment (2), and a number of effective vaccines have been developed and marketed (3). However, unexplained issues still remain. Among them, a particularly debated issue, by both patients and researchers, has been the recognition that a relevant percentage of patients with COVID-19 experience persisting symptoms after the resolution of acute disease. While patients relatively quickly highlighted their persisting symptoms and change in quality of life, Italian researchers first documented this on an International peer-reviewed journal (4). Carfi et al found that in patients who had recovered from COVID-19, 87.4\% reported persistence of at least one symptom, particularly fatigue and dyspnoea. Later, several other papers confirmed these data in adults and a recent large cohort of 1,733 patients from Wuhan found persistent symptoms in $76 \%$ of patients 6 months after initial diagnosis (5).

Since this condition is still not completely understood, a definite official name was not initially recognized. Nevertheless, patient organizations started complex discussions and movements on social media with various kinds of evidence and advocacy to demonstrate a longer, more complex course of illness than laid out in initial reports from Wuhan and, eventually, coined the term Long COVID (6) which was, later, also recognized by the World Health Organization (7). Long COVID is probably the first illness named directly from patients.

Researchers have only recently began to study why people develop these symptoms. According to the WHO, several explanations can be considered (7): persistence of the virus in some parts of the body that are sheltered from the immune system, such as the brain; direct damage to organs, such as the heart and lungs, and also the pancreas, causing some new cases of diabetes; and blood clotting, which can cause heart attacks and strokes. However, there is a huge variety in both the pattern of symptoms and their severity, with gender and, possibly, age differences. 
While at the beginning children were considered relatively spared by the pandemic, around December parent movements began highlighting that most children never recovered from acute COVID-19. Parents developed social media movements aiming to highlight that children were also suffering from Long COVID. The Long COVID Kids UK (https://www.longCOVIDkids.org/) began initially with the launch of an online message on YouTube on October 31 2020 (https://www.youtube.com/watch?v=RiIambG8vs0) and with Facebook and Twitter channels. Since its start, 197,000 people have been reached on Facebook and 1.8 million interactions on Twitter. So far, the group includes over 1,800 children from 1,332 families (Appendix figures). Later, a case series from Sweden described a group of five children with Long COVID (8). A larger study from Italy confirmed that about one out of three children with acute COVID-19 experienced persisting symptoms months after initial diagnosis (9).

Considering the importance of patient-driven data in this pandemic and for the understanding of Long COVID in particular, and aiming to provide more insights in the burden of Long COVID in children, one of the largest parent movements (Long COVID Kids UK) performed an online follow-up survey of a large cohort of children that experienced COVID-19 and had persisting symptoms.

\section{Methods}

\section{Long COVID Kids Rapid Survey 2}

In order to assess the presence of persisting symptoms in children with previous COVID-19, the parents non-profit association LongCOVIDKids developed an online platform where parents from all over the world can access and anonymously report their child's experience. The 'Long COVID Kids Rapid Survey 2' was designed as a follow-up to a pilot survey (that established quantity and type of symptoms) as a means to establish clusters of symptoms rather than the full breadth of symptoms as well as the effects on the mental and physical health of the child as a result of Long COVID. Certain symptoms were deliberately excluded as they were not considered relevant to the clusters under consideration. Links to the survey site on JotForm were disseminated on the closed Facebook group LongCOVIDKids. Parents' 
consent was required before answering questions on their children with COVID-19 persistent symptoms.

In the 'Long COVID Kids Rapid Survey 2', participants were asked to self-declare the following main information on their children: how COVID-19 was confirmed and details at infection, including need of hospitalization, age, sex and ethnicity; month of initial infection; course of symptoms, if any, from initial infection; activity before after infection; mental health status and comorbidities before COVID-19; displayed symptoms since COVID-19; behavioural/activity/habits changes after COVID-19; need of medical care after COVID-19; parents' perspectives of need of medical care for their children and type of care; parents' perspective on child's need of support to be readmitted at school after COVID-19. The full version of the survey is available at https://form.jotform.com/210431051528039?fbclid=IwAR3uYxbqOAFc008o73Dhc5kolP8aaTx0wY_ba7MvIQ83UxHEy6eBLpH720

For the purpose of this study, we used data from the 'Long COVID Kids Rapid Survey 2' collected between 13 February 2021 and 06 March 2021. Only those children with symptoms lasting longer than 4 weeks were included. Given the nature of the survey, an Ethic Committee was not necessary for this study.

\section{Data Analysis}

The Confirmation status of COVID-19 infection was asked about as "Has your child had confirmed or suspected COVID-19 infection?". The possible answers to that question were: “Clinical Diagnosis", "Lateral Flow”, "Positive PCR Swab”, and "Unconfirmed by a test or medical professional but we think we had it." We will initially report the counts for the original possible answers, and then in tables we will use a simplified version by merging "Positive PCR Swab" and "Lateral Flow" as "Positive Test". Time from infection was estimated (with a 15-day uncertainty) by subtracting the 15th day of the reported month of (confirmed or suspected) infection from the date of response to the survey. Children with an estimated time from infection below 1.5 months were excluded to ensure that all included children had had symptoms for longer than 4 weeks. In practice this implied excluding all children 
infected on February 2021 and those infected on January 2021 and reported on February 2021.

We produced summary tables and graphs aiming at the description of the study sample, the symptoms and changes in Long-COVID children, looking further at changes in their physical activity levels and mental health. We cross-tabulated variables by confirmation status of COVID-19 infection and by the pre-existence of comorbidities.

\section{Results}

\section{Study Sample}

Data on 510 children who had had COVID-19 for more than 4 weeks were reported by their parents. 351 (68.8\%) of them live in the UK and 94 (18.4\%) in the USA. They got COVID-19 between January 2020 and January 2021 at a mean age of 10.3 years (standard deviation 3.8) (Figure 1, left). 287 (56.3\%) were female. For 297 (58.2\%) children COVID-19 has been confirmed by a positive PCR test $(\mathrm{N}=141)$, a positive (antibody) lateral flow test $(\mathrm{N}=4)$ or clinical diagnosis ( $\mathrm{N}=156)$. For 209 (41\%) children, COVID-19 was suspected but has not been confirmed by a test or medical professional; most of those children are from UK and were infected around March 2020, at a time when access to tests, particularly for non-severe cases, was difficult in most countries (Table 1).

Age at COVID-19 infection

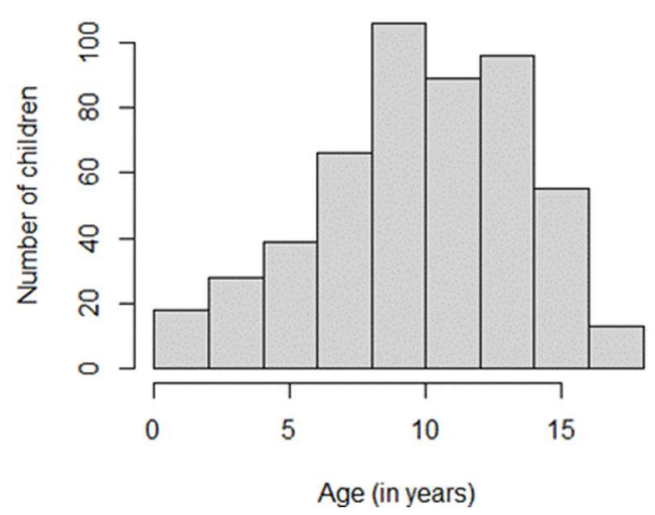

Time from COVID-19 infection

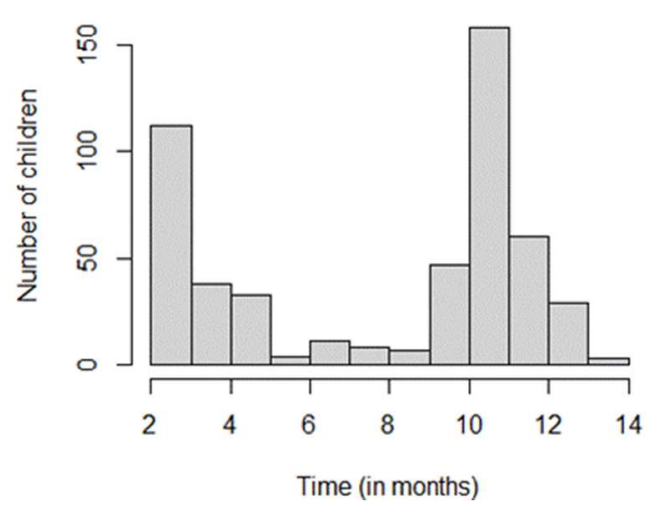

Figure 1. Age of respondents at COVID-19 infection (left) and time from infection at date of response to the 'Long COVID Kids Rapid Survey 2' questionnaire (right). 
Table 1. Confirmation status of COVID-19 infection, by country of residence and by time from infection

\begin{tabular}{|c|c|c|c|c|c|c|}
\hline \multirow[t]{2}{*}{$\begin{array}{l}\text { Confirmation } \\
\text { status }\end{array}$} & \multicolumn{3}{|c|}{ Country of Residence } & \multicolumn{3}{|c|}{ Time from infection } \\
\hline & UK & USA & Other & $\begin{array}{c}1-2 \\
\text { months }\end{array}$ & $\begin{array}{c}3-6 \\
\text { months }\end{array}$ & $7+$ months \\
\hline & $N=351$ & $N=94$ & $N=65$ & $N=82$ & $N=108$ & $N=320$ \\
\hline Clinical Diagnosis & $100(28.5 \%)$ & $39(41.5 \%)$ & $17(26.2 \%)$ & $13(15.9 \%)$ & $21(19.4 \%)$ & $122(38.1 \%)$ \\
\hline Positive Test & $83(23.6 \%)$ & 37 (39.4\%) & $25(38.5 \%)$ & $64(78 \%)$ & $60(55.6 \%)$ & $21(6.6 \%)$ \\
\hline $\begin{array}{l}\text { Unconfirmed but } \\
\text { suspected }\end{array}$ & $168(47.9 \%)$ & $18(19.1 \%)$ & $23(35.4 \%)$ & $5(6.1 \%)$ & $27(25 \%)$ & $177(55.3 \%)$ \\
\hline
\end{tabular}

At their initial COVID-19 infection, only 22 (4.3\%) children were hospitalized; 62 (12.2\%) were asymptomatic, 378 (74.1\%) were managed at home, and 48 (9.4\%) went to hospital but were not admitted. 223 (43.7\%) children had no pre-existing condition. Detailed information on pre-COVID conditions of children is available in the Appendix Table A1. 411 $(80.6 \%)$ children had no pre-COVID mental health concern or diagnosis.

\section{Persistence of symptoms in children since COVID-19}

Overall, children had persisting COVID-19 for a mean of 8.2 months (standard deviation 3.9)

(Figure 1, right). Details of reported symptoms are described in Table 2. Most frequent symptoms were: Tiredness and weakness (444 patients, $87.1 \%$ of sample), Fatigue (410, $80.4 \%)$, Headache $(401,78.6 \%)$, Tummy pain or cramps $(387,75.9 \%)$, Muscle aches and pains $(349,68.4 \%)$, Muscle and joint pain (309, 60.6\%), Post-exertional malaise (274, 53.7\%), A rash (267, 52.4\%), Unexplained irritability $(262,51.4 \%)$, and Dizziness (245, 48\%). 484 (94.9\%) children had at least four symptoms. Appendix Table A2 reports symptoms according to disease diagnosis and pre-existence of comorbidities.

129 (25.3\%) children have suffered constant COVID-19 infection symptoms, 252 (49.4\%) have had periods of apparent recovery and then symptoms returning, and 97 (19\%) had a prolonged period of wellness followed by symptoms. Among those who had no pre-COVID condition it was slightly less frequent to have constant COVID-19 (23.8\% versus 26.5\%) or alternating recovery/symptom episodes (48.4\% versus $50.2 \%$ ) (Table 3 ). 
Table 2. Symptoms present since COVID-19 infection (multiple choices allowed), by the pre-existence of comorbidity conditions, by sex, by age group, and by time from infection

\begin{tabular}{|c|c|c|c|c|c|c|c|c|c|c|}
\hline Symptom & $\begin{array}{c}\text { All } \\
N=510\end{array}$ & $\begin{array}{l}\text { Had Pre- } \\
\text { conditions } \\
\quad N=287\end{array}$ & $\begin{array}{l}\text { No Pre- } \\
\text { conditions } \\
N=223\end{array}$ & $\begin{array}{l}\text { Female } \\
N=287\end{array}$ & $\begin{array}{l}\text { Male } \\
N=222\end{array}$ & $\begin{array}{c}\text { Age less } \\
\text { than } 10 \text { yrs } \\
N=196\end{array}$ & $\begin{array}{l}\text { Age } 10 \text { yrs } \\
\text { or older } \\
\quad N=314\end{array}$ & $\begin{array}{c}1-2 \\
\text { months } \\
N=82\end{array}$ & $\begin{array}{c}\text { 3- } 6 \\
\text { months } \\
N=108\end{array}$ & $\begin{array}{c}7+ \\
\text { months } \\
N=320\end{array}$ \\
\hline \multicolumn{11}{|l|}{ Cardio-respiratory } \\
\hline Heart palpitations & $205(40.2 \%)$ & $112(39 \%)$ & $93(41.7 \%)$ & $121(42.2 \%)$ & $83(37.4 \%)$ & $71(36.2 \%)$ & $\begin{array}{r}134 \\
(42.7 \%)\end{array}$ & $29(35.4 \%)$ & $45(41.7 \%)$ & 131 (40.9\%) \\
\hline Coughing & $151(29.6 \%)$ & $81(28.2 \%)$ & 70 (31.4\%) & $79(27.5 \%)$ & $71(32 \%)$ & $66(33.7 \%)$ & 85 (27.1\%) & $25(30.5 \%)$ & $30(27.8 \%)$ & $96(30 \%)$ \\
\hline Throat clearing & $107(21 \%)$ & 59 (20.6\%) & 48 (21.5\%) & $59(20.6 \%)$ & $47(21.2 \%)$ & $55(28.1 \%)$ & $52(16.6 \%)$ & $21(25.6 \%)$ & $16(14.8 \%)$ & 70 (21.9\%) \\
\hline \multicolumn{11}{|l|}{ Dermatologic } \\
\hline A rash & $267(52.4 \%)$ & $\begin{array}{r}149 \\
(51.9 \%)\end{array}$ & $118(52.9 \%)$ & $143(49.8 \%)$ & $123(55.4 \%)$ & $\begin{array}{r}118 \\
(60.2 \%)\end{array}$ & $\begin{array}{r}149 \\
(47.5 \%)\end{array}$ & $35(42.7 \%)$ & $54(50 \%)$ & $178(55.6 \%)$ \\
\hline Red and cracked lips & $201(39.4 \%)$ & 112 (39\%) & 89 (39.9\%) & $124(43.2 \%)$ & 77 (34.7\%) & 89 (45.4\%) & $\begin{array}{r}112 \\
(35.7 \%)\end{array}$ & $33(40.2 \%)$ & $37(34.3 \%)$ & 131 (40.9\%) \\
\hline $\begin{array}{l}\text { Peeling skin on your } \\
\text { hands and feet }\end{array}$ & $143(28 \%)$ & $83(28.9 \%)$ & $60(26.9 \%)$ & $78(27.2 \%)$ & 65 (29.3\%) & $63(32.1 \%)$ & $80(25.5 \%)$ & $20(24.4 \%)$ & $26(24.1 \%)$ & $97(30.3 \%)$ \\
\hline Swollen hands and feet & $107(21 \%)$ & $56(19.5 \%)$ & $51(22.9 \%)$ & $62(21.6 \%)$ & 45 (20.3\%) & $42(21.4 \%)$ & 65 (20.7\%) & $10(12.2 \%)$ & $14(13 \%)$ & $83(25.9 \%)$ \\
\hline Ulcers & $79(15.5 \%)$ & $43(15 \%)$ & $36(16.1 \%)$ & $51(17.8 \%)$ & $28(12.6 \%)$ & 47 (24\%) & $32(10.2 \%)$ & $10(12.2 \%)$ & $11(10.2 \%)$ & $58(18.1 \%)$ \\
\hline \multicolumn{11}{|l|}{ Gastrointestinal } \\
\hline Tummy pain or cramps & $387(75.9 \%)$ & $218(76 \%)$ & $169(75.8 \%)$ & $225(78.4 \%)$ & $161(72.5 \%)$ & $\begin{array}{r}157 \\
(80.1 \%)\end{array}$ & $\begin{array}{r}230 \\
(73.2 \%)\end{array}$ & $58(70.7 \%)$ & $78(72.2 \%)$ & $251(78.4 \%)$ \\
\hline Nausea & $233(45.7 \%)$ & $\begin{array}{r}134 \\
(46.7 \%)\end{array}$ & 99 (44.4\%) & $135(47 \%)$ & $97(43.7 \%)$ & $78(39.8 \%)$ & $\begin{array}{r}155 \\
(49.4 \%)\end{array}$ & $35(42.7 \%)$ & $52(48.1 \%)$ & $146(45.6 \%)$ \\
\hline $\begin{array}{l}\text { Diarrhoea and } \\
\text { vomiting }\end{array}$ & $216(42.4 \%)$ & $\begin{array}{r}128 \\
(44.6 \%)\end{array}$ & 88 (39.5\%) & 115 (40.1\%) & $100(45 \%)$ & $92(46.9 \%)$ & $\begin{array}{r}124 \\
(39.5 \%)\end{array}$ & $34(41.5 \%)$ & $44(40.7 \%)$ & $138(43.1 \%)$ \\
\hline \multicolumn{11}{|l|}{$\begin{array}{l}\text { HEENT (Head, Ears, } \\
\text { Eyes, Nose, Throat) }\end{array}$} \\
\hline Red eyes & $206(40.4 \%)$ & $\begin{array}{r}113 \\
(39.4 \%)\end{array}$ & $93(41.7 \%)$ & $102(35.5 \%)$ & $104(46.8 \%)$ & $87(44.4 \%)$ & $\begin{array}{r}119 \\
(37.9 \%)\end{array}$ & $30(36.6 \%)$ & $41(38 \%)$ & $135(42.2 \%)$ \\
\hline Sore throat & $230(45.1 \%)$ & $132(46 \%)$ & $98(43.9 \%)$ & $131(45.6 \%)$ & 99 (44.6\%) & $87(44.4 \%)$ & $\begin{array}{r}143 \\
(45.5 \%)\end{array}$ & $36(43.9 \%)$ & $43(39.8 \%)$ & $151(47.2 \%)$ \\
\hline Swollen neck glands & $128(25.1 \%)$ & $74(25.8 \%)$ & $54(24.2 \%)$ & $81(28.2 \%)$ & $47(21.2 \%)$ & $46(23.5 \%)$ & $82(26.1 \%)$ & $19(23.2 \%)$ & $21(19.4 \%)$ & $88(27.5 \%)$ \\
\hline
\end{tabular}




\begin{tabular}{|c|c|c|c|c|c|c|c|c|c|c|}
\hline $\begin{array}{l}\text { Muscle aches and } \\
\text { pains }\end{array}$ & 349 (68.4\%) & $\begin{array}{r}204 \\
(71.1 \%)\end{array}$ & $145(65 \%)$ & $201(70 \%)$ & $147(66.2 \%)$ & $\begin{array}{r}111 \\
(56.6 \%)\end{array}$ & $\begin{array}{r}238 \\
(75.8 \%)\end{array}$ & 60 (73.2\%) & 70 (64.8\%) & 219 (68.4\%) \\
\hline Muscle and joint pain & 309 (60.6\%) & $\begin{array}{r}179 \\
(62.4 \%)\end{array}$ & $130(58.3 \%)$ & $180(62.7 \%)$ & $129(58.1 \%)$ & $102(52 \%)$ & $\begin{array}{r}207 \\
(65.9 \%)\end{array}$ & $51(62.2 \%)$ & 69 (63.9\%) & 189 (59.1\%) \\
\hline \multicolumn{11}{|l|}{ Neurological } \\
\hline Headache & $401(78.6 \%)$ & $\begin{array}{r}239 \\
(83.3 \%)\end{array}$ & $162(72.6 \%)$ & $231(80.5 \%)$ & 169 (76.1\%) & $\begin{array}{r}138 \\
(70.4 \%)\end{array}$ & $\begin{array}{r}263 \\
(83.8 \%)\end{array}$ & $63(76.8 \%)$ & 86 (79.6\%) & $252(78.8 \%)$ \\
\hline Unexplained irritability & 262 (51.4\%) & $\begin{array}{r}149 \\
(51.9 \%)\end{array}$ & $113(50.7 \%)$ & $150(52.3 \%)$ & $112(50.5 \%)$ & $\begin{array}{r}117 \\
(59.7 \%)\end{array}$ & $\begin{array}{r}145 \\
(46.2 \%)\end{array}$ & $41(50 \%)$ & 56 (51.9\%) & 165 (51.6\%) \\
\hline Dizziness & $245(48 \%)$ & $\begin{array}{r}148 \\
(51.6 \%)\end{array}$ & $97(43.5 \%)$ & $150(52.3 \%)$ & $94(42.3 \%)$ & $60(30.6 \%)$ & $\begin{array}{r}185 \\
(58.9 \%)\end{array}$ & 39 (47.6\%) & 55 (50.9\%) & $151(47.2 \%)$ \\
\hline Twitches & $55(10.8 \%)$ & $34(11.8 \%)$ & $21(9.4 \%)$ & $35(12.2 \%)$ & $20(9 \%)$ & $16(8.2 \%)$ & $39(12.4 \%)$ & $9(11 \%)$ & $10(9.3 \%)$ & $36(11.2 \%)$ \\
\hline Word repetition & $52(10.2 \%)$ & $25(8.7 \%)$ & 27 (12.1\%) & $29(10.1 \%)$ & $22(9.9 \%)$ & 21 (10.7\%) & 31 (9.9\%) & $7(8.5 \%)$ & $14(13 \%)$ & $31(9.7 \%)$ \\
\hline Tics & 47 (9.2\%) & $25(8.7 \%)$ & $22(9.9 \%)$ & $26(9.1 \%)$ & $21(9.5 \%)$ & $18(9.2 \%)$ & $29(9.2 \%)$ & $5(6.1 \%)$ & $8(7.4 \%)$ & 34 (10.6\%) \\
\hline Stuttering & $40(7.8 \%)$ & $17(5.9 \%)$ & $23(10.3 \%)$ & $23(8 \%)$ & $17(7.7 \%)$ & $15(7.7 \%)$ & $25(8 \%)$ & $4(4.9 \%)$ & $7(6.5 \%)$ & 29 (9.1\%) \\
\hline Swearing & $26(5.1 \%)$ & $15(5.2 \%)$ & $11(4.9 \%)$ & $9(3.1 \%)$ & $17(7.7 \%)$ & $10(5.1 \%)$ & $16(5.1 \%)$ & $2(2.4 \%)$ & $5(4.6 \%)$ & 19 (5.9\%) \\
\hline Growling & $24(4.7 \%)$ & $12(4.2 \%)$ & $12(5.4 \%)$ & $11(3.8 \%)$ & $12(5.4 \%)$ & $15(7.7 \%)$ & $9(2.9 \%)$ & $5(6.1 \%)$ & $4(3.7 \%)$ & $15(4.7 \%)$ \\
\hline \multicolumn{11}{|l|}{ General } \\
\hline $\begin{array}{l}\text { Tiredness and } \\
\text { weakness }\end{array}$ & 444 (87.1\%) & $\begin{array}{r}249 \\
(86.8 \%)\end{array}$ & 195 (87.4\%) & $248(86.4 \%)$ & $195(87.8 \%)$ & $\begin{array}{r}168 \\
(85.7 \%)\end{array}$ & $\begin{array}{r}276 \\
(87.9 \%)\end{array}$ & 70 (85.4\%) & $98(90.7 \%)$ & 276 (86.2\%) \\
\hline Fatigue & $410(80.4 \%)$ & $\begin{array}{r}235 \\
(81.9 \%)\end{array}$ & 175 (78.5\%) & $236(82.2 \%)$ & 173 (77.9\%) & $\begin{array}{r}142 \\
(72.4 \%)\end{array}$ & $\begin{array}{r}268 \\
(85.4 \%)\end{array}$ & $64(78 \%)$ & 93 (86.1\%) & $253(79.1 \%)$ \\
\hline Post-exertional malaise & $274(53.7 \%)$ & $\begin{array}{r}161 \\
(56.1 \%)\end{array}$ & $113(50.7 \%)$ & $158(55.1 \%)$ & $116(52.3 \%)$ & 95 (48.5\%) & $179(57 \%)$ & 44 (53.7\%) & $57(52.8 \%)$ & 173 (54.1\%) \\
\hline Fever & $151(29.6 \%)$ & $81(28.2 \%)$ & 70 (31.4\%) & $94(32.8 \%)$ & $56(25.2 \%)$ & 68 (34.7\%) & $83(26.4 \%)$ & $22(26.8 \%)$ & $29(26.9 \%)$ & $100(31.2 \%)$ \\
\hline Flu-like symptoms & $121(23.7 \%)$ & $69(24 \%)$ & $52(23.3 \%)$ & $78(27.2 \%)$ & 42 (18.9\%) & $47(24 \%)$ & 74 (23.6\%) & $20(24.4 \%)$ & 20 (18.5\%) & 81 (25.3\%) \\
\hline \multicolumn{11}{|l|}{ Other } \\
\hline Sepsis & $7(1.4 \%)$ & $5(1.7 \%)$ & $2(0.9 \%)$ & $4(1.4 \%)$ & $3(1.4 \%)$ & $3(1.5 \%)$ & $4(1.3 \%)$ & $0(0 \%)$ & $1(0.9 \%)$ & $6(1.9 \%)$ \\
\hline Appendicitis & $7(1.4 \%)$ & $6(2.1 \%)$ & $1(0.4 \%)$ & $5(1.7 \%)$ & $2(0.9 \%)$ & $4(2 \%)$ & $3(1 \%)$ & $0(0 \%)$ & $0(0 \%)$ & $7(2.2 \%)$ \\
\hline Peritonitis & $1(0.2 \%)$ & $0(0 \%)$ & $1(0.4 \%)$ & $0(0 \%)$ & $1(0.5 \%)$ & $0(0 \%)$ & $1(0.3 \%)$ & $0(0 \%)$ & $0(0 \%)$ & $1(0.3 \%)$ \\
\hline
\end{tabular}


Table 3. Children experience of COVID-19 by confirmation status of COVID-19 infection, and by the pre-existence of comorbidity conditions

\begin{tabular}{|c|c|c|c|c|c|c|}
\hline & $\begin{array}{c}\text { All } \\
N=510\end{array}$ & $\begin{array}{c}\begin{array}{c}\text { Clinical } \\
\text { Diagnosis }\end{array} \\
N=156\end{array}$ & $\begin{array}{c}\begin{array}{c}\text { Positive } \\
\text { Test }\end{array} \\
N=145\end{array}$ & $\begin{array}{c}\text { Unconfirmed } \\
\text { but suspected } \\
\quad N-209 \\
\end{array}$ & $\begin{array}{c}\text { Had Pre- } \\
\text { Conditions } \\
\quad N=287\end{array}$ & $\begin{array}{c}\begin{array}{c}\text { No Pre- } \\
\text { Conditions } \\
N=223\end{array} \\
\end{array}$ \\
\hline Constant COVID-19 & $129(25.3 \%)$ & $45(28.8 \%)$ & $50(34.5 \%)$ & $34(16.3 \%)$ & $76(26.5 \%)$ & $53(23.8 \%)$ \\
\hline $\begin{array}{l}\text { Alternance } \\
\text { recovery/symptoms }\end{array}$ & 252 (49.4\%) & $78(50 \%)$ & $66(45.5 \%)$ & $108(51.7 \%)$ & $144(50.2 \%)$ & $108(48.4 \%)$ \\
\hline $\begin{array}{l}\text { Long wellness } \\
\text { followed by } \\
\text { symptoms }\end{array}$ & 97 (19\%) & $21(13.5 \%)$ & $24(16.6 \%)$ & $52(24.9 \%)$ & $46(16 \%)$ & $51(22.9 \%)$ \\
\hline Undetermined & $32(6.3 \%)$ & $12(7.7 \%)$ & $5(3.4 \%)$ & $15(7.2 \%)$ & $21(7.3 \%)$ & $11(4.9 \%)$ \\
\hline
\end{tabular}

\section{Changes in children since COVID-19 infection}

Long-COVID children have suffered complex changes since COVID-19 infection (Figure 2 and Appendix Table A3). The most frequently reported changes are in: Energy levels (425 patients, $83.3 \%$ of sample), Mood (300, 58.8\%), Sleep (287, 56.3\%), and Appetite (253, 49.6\%). The latter changes were significant on children with confirmed/unconfirmed COVID-19 and occurred similarly on those with or without pre-existing conditions (Figure 2 and Appendix Table A3). Overall, all children have had at least 1 change and 325 (63.7\%) children have had at least 4 changes from those in Table 4 since their COVID-19 infection. The proportion of those with at least 4 changes is above $60 \%$ independently of whether they had had pre-COVID conditions (Appendix Table A4). 

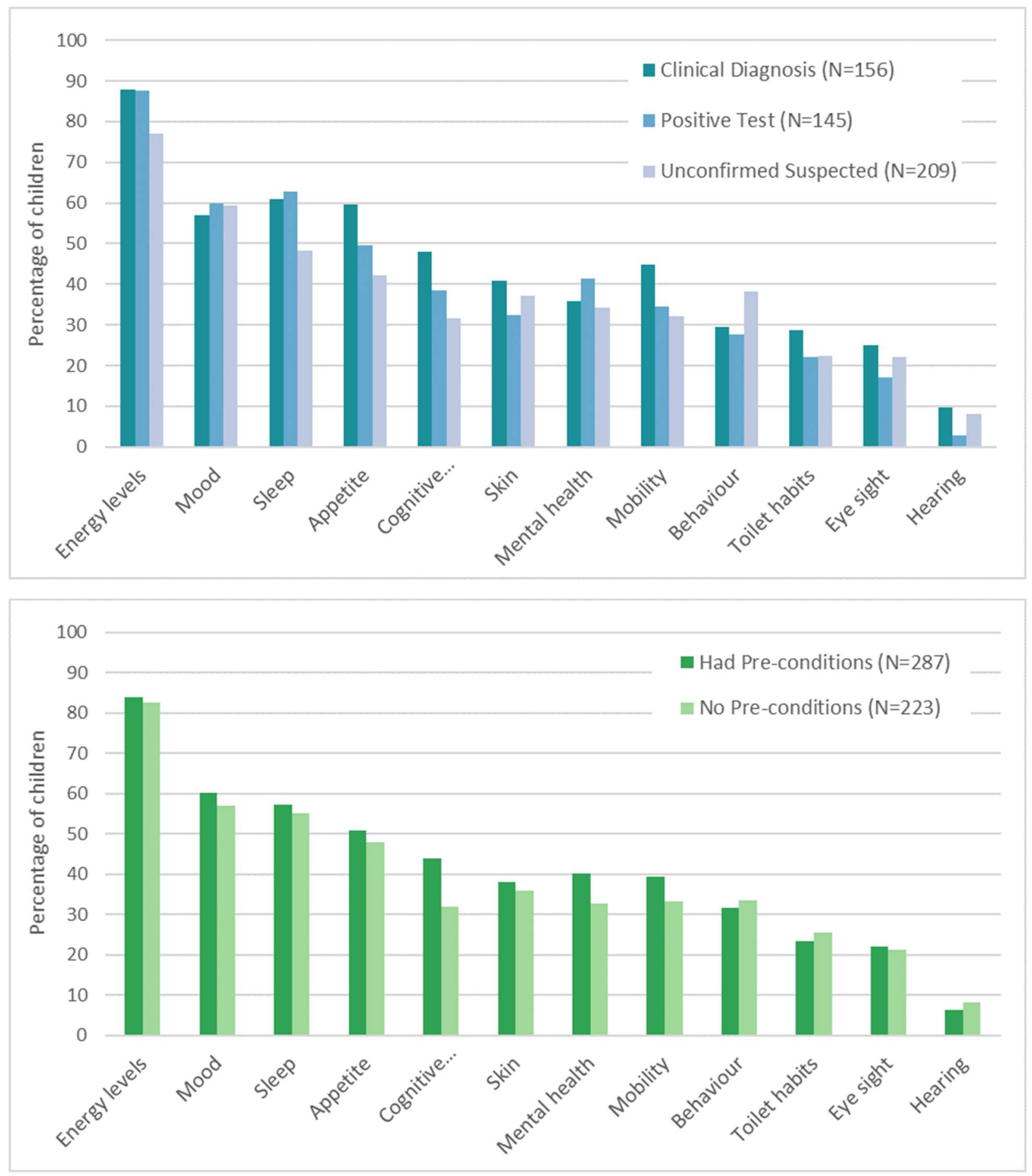

Figure 2. Changes reported since COVID-19 infection by confirmation status of infection (left), and by the pre-existence of comorbidity conditions (right). 


\section{Changes in Physical Activity Levels}

Most children were physically active before their COVID-19 infection. During the first 6 weeks after infection, 262 (51.4\%) children did participate in some level of activity, 217 (42.5\%) did not, and for 31 (6.1\%) children their parents were unsure.

Families reported that their children activity levels were worse than before infection (Appendix tables A5 and A6). Only 51 (10\%) children have returned to previous levels of activity. 108 (21.2\%) are currently unable to enjoy any activity, and 154 (30.2\%) enjoy occasional activity but usually have an increase of symptoms after. Overall, the more physically active they were before COVID-19, the higher the proportion of them who returned to previous activity levels, although these rates are very low: only 17 (11.8\%) of those who practiced daily sports before COVID-19 returned to previous levels.

\section{Changes in Mental Health}

Parents reported a significant prevalence of Neuropsychiatric symptoms among their children with persisting symptoms (Figure 3 and Appendix Table A7). In more detail, several parents reported Lack of concentration (309 children, 60.6\% of sample), Difficulty remembering information (234, 45.9\%), Difficulty in doing everyday tasks (204, 40\%), Difficulty processing information $(167,32.7 \%)$, and Short term memory issues $(167,32.7 \%)$. $279(54.7 \%)$ children have had at least 3 mental health issues (excluding "None of the above" and "Other"), 45 (8.8\%) children have had 2 issues, 54 (10.6\%) children have had 1 issue, and 132 (25.9\%) children have had no issues (excluding "None of the above" and "Other"). Only $64(28.7 \%)$ of those with no pre-COVID conditions haven't had any mental health/cognitive issues since their COVID infection (Appendix Table A8). 

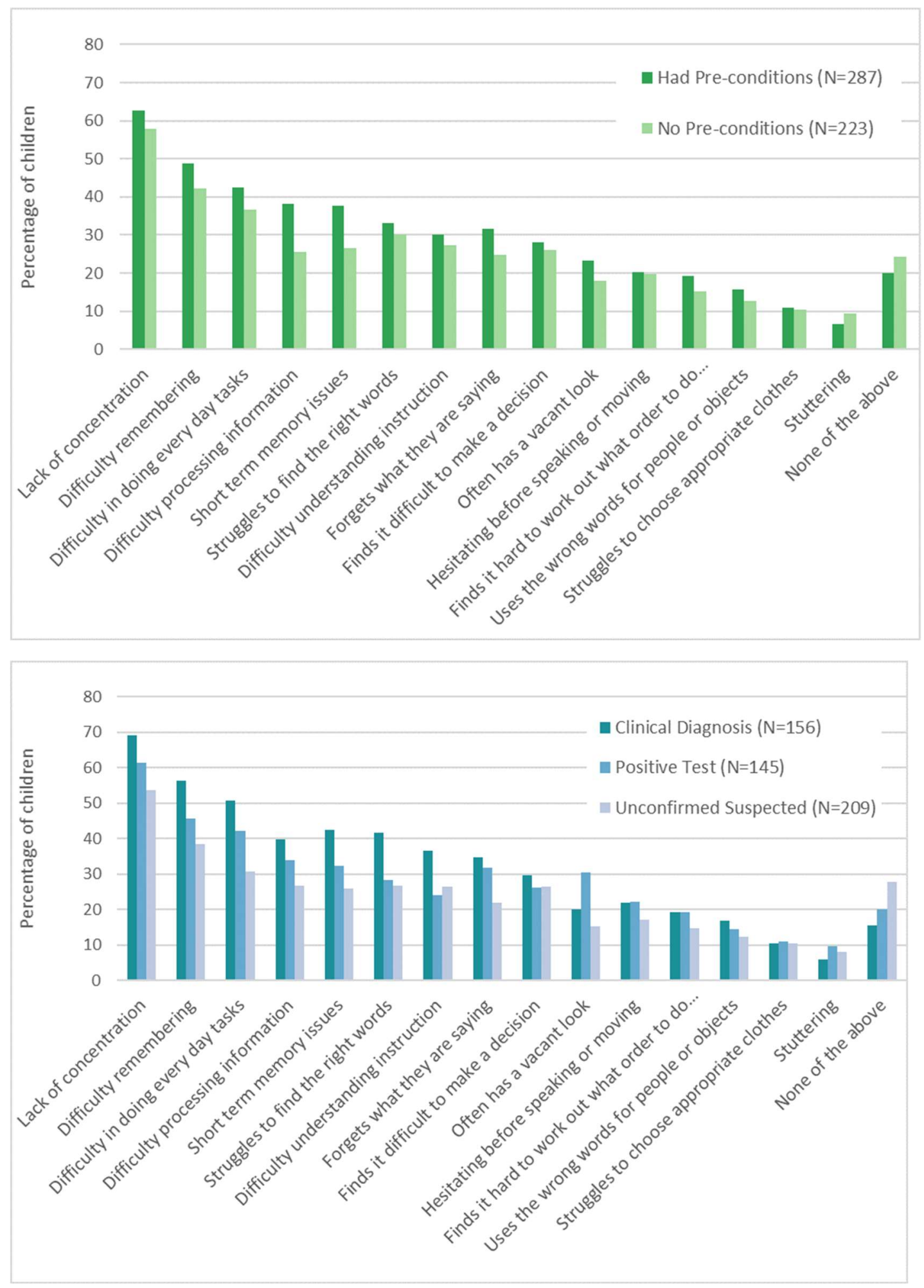

Figure 3. Mental health / cognitive issues since COVID-19 infection (multiple issues per child are usual) by confirmation status of infection (top), and by the pre-existence of comorbidity conditions (bottom) 


\section{Discussion}

In this study, we performed a comprehensive assessment of parents' perspectives about long-term physical and mental health outcomes of a large cohort of children with persisting symptoms after initial COVID-19 infection, providing details about reported symptoms, their dynamics and the overall changes in children activities and mental health.

We found that fatigue, headache, muscle and joint pain, post-exertional malaise, rashes, heart palpitations were commonly reported by parents. This cluster of symptoms were frequently reported in another paediatric Long COVID study from Italy, where insomnia (18.6\%), respiratory symptoms (including pain and chest tightness) (14.7\%), nasal congestion (12.4\%), fatigue (10.8\%), muscle (10.1\%) and joint pain (6.9\%), and concentration difficulties (10.1), were the most frequently reported symptoms (9). In the Italian study, 35 children (27.1\%) had at least one symptom 120 days or more after diagnosis, and 29 out of the 68 (42.6\%) children assessed $\geq 120$ days from diagnosis were still distressed by these symptoms. A similar pattern of symptoms was reported in a small case series published in Sweden by Ludvigsson (8), which reported five children having fatigue, dyspnoea, heart palpitations or chest pain, headaches, difficulties concentrating, muscle weakness, dizziness and sore throats months from initial diagnosis. While some had improved after 6-8 months, none had fully returned to school. Interestingly, the UK, Italian and Swedish patients had similar age patterns. Of note, adults' studies on Long COVID report a very similar pattern of symptoms as well $(4,5)$. The similarity of the reported symptoms in different cohorts of adult and paediatric studies suggest that those may be the defining symptoms of Long COVID in general, including in children.

In this survey, we assessed symptom dynamics. This is an important aspect of Long COVID according to descriptions of patient organizations and adults' studies, while it was not assessed in children before. Interestingly, we found that $25.3 \%$ of children have suffered constant COVID-19 infection symptoms, 49.4\% have had periods of apparent recovery and then symptoms returning, $19.0 \%$ had a prolonged period of wellness followed by symptoms. Importantly, a similar pattern was reported independently in those with and without preexisting conditions. To date, we did not find any paediatric study to compare our data. 
Since physical activity plays an important role in child health, growth, development and socialization, we assessed how it changed after the infection of COVID-19. Overall, we found that most children had worse activity levels than before infection, since, at the time of the survey, $21.2 \%$ were currently unable to enjoy any activity and $30.2 \%$ enjoyed occasional activity but usually had an increase of symptoms after. Although lockdown and school closure may have contributed to this change (10), from our survey it seems that physical conditions were the main limiting factor for not enjoying physical activity.

We also assessed mental health issues in this cohort of children with previous COVID-19. During the last months of the pandemic, healthcare professionals seeing an increase in suicide attempts and other issues related with mental health in children and adolescents have raised several warnings $(11,12)$. Parents reported a wide range of neuro-cognitive symptoms, including lack of concentration, difficulty processing/remembering information or understanding instruction, short term memory issues and struggles to find the right words. Similar problems have been reported in the only paediatric study performed so far (9) and in several adult studies $(4,5)$.

This study has several limitations to address. First, it is an online survey that was only shared through an online platform and not systematically proposed to consecutively diagnosed children within specific settings, therefore determining a selection bias. Also, this survey has been launched on the page of Long COVID Kids UK, which was created with the purpose to provide awareness and support to families with children with Long COVID. Therefore, parents of children with persisting symptoms may have had more interest in participating in this survey, and this can explain the large number of children with persisting symptoms in this cohort, when compared with other cohorts. Therefore, we were not able to define the incidence of Long COVID in children. Another limitation is that not all children received a microbiologically confirmed diagnosis. This is mainly due to unpreparedness of health systems (13) and difficulties in access to test, particularly during the first months of the pandemic, and because of different decision-rules practices in different settings. Also, the small number of children requiring hospitalization did not allow us to determine how initial severity affected long COVID in children. Last, the lack of a control group cannot allow us to determine a cause-effect link between COVID-19 and these symptoms. 
In conclusion, we described a cluster of the most frequent symptoms and its dynamics in children with Long COVID in a large cohort of children. Symptoms like fatigue, headache, muscle and joint pain, rashes and heart palpitations, and mental health issues like lack of concentration and short memory problems, were particularly frequent and confirm previous observations, suggesting that they may characterize this condition. A better comprehension of Long COVID is urgently needed, considering that at the moment there are no therapeutic options for these children that, months after COVID-19, still struggle to come back to a normal life.

Acknowledgments: We are grateful to all parents that decided to participate in this survey to raise awareness of Long COVID in children. We are grateful to Professor Christina Pagel (Clinical Operational Research Unit, University College London, UK) for reviewing an early version of the presented results.

Data availability statement: Dataset available upon reasonable request to the corresponding author.

Conflict of Interests: SM and FKS are co-founders of Long COVID Kids UK. While they developed the survey and were responsible to share the page online, they had no role in the data analysis, which was performed independently by DB and FEP.

Funding: Nothing to declare.

\section{References}

1- $\mathrm{Hu}$ B, Guo H, Zhou P, Shi ZL. Characteristics of SARS-CoV-2 and COVID-19. Nat Rev Microbiol. 2021 Mar;19(3):141-154. doi: 10.1038/s41579-020-00459-7. Epub 2020 Oct 6. PMID: 33024307; PMCID: PMC7537588.

2- RECOVERY Collaborative Group, Horby P, Lim WS, Emberson JR, Mafham M, Bell JL, Linsell L, Staplin N, Brightling C, Ustianowski A, Elmahi E, Prudon B, Green C, Felton T, Chadwick D, Rege K, Fegan C, Chappell LC, Faust SN, Jaki T, Jeffery K, Montgomery 
A, Rowan K, Juszczak E, Baillie JK, Haynes R, Landray MJ. Dexamethasone in Hospitalized Patients with COVID-19. N Engl J Med. 2021 Feb 25;384(8):693-704. doi: 10.1056/NEJMoa2021436. Epub 2020 Jul 17. PMID: 32678530; PMCID: PMC7383595.

3- Bettini E, Locci M. SARS-CoV-2 mRNA Vaccines: Immunological Mechanism and Beyond. Vaccines (Basel). 2021 Feb 12;9(2):147. doi: 10.3390/vaccines9020147. PMID: 33673048.

4- Carfi A, Bernabei R, Landi F; Gemelli Against COVID-19 Post-Acute Care Study Group. Persistent Symptoms in Patients After Acute COVID-19. JAMA. 2020 Aug 11;324(6):603- 605. doi: 10.1001/jama.2020.12603. PMID: 32644129; PMCID: PMC7349096.

5- Huang C, Huang L, Wang Y, Li X, Ren L, Gu X, Kang L, Guo L, Liu M, Zhou X, Luo J, Huang Z, Tu S, Zhao Y, Chen L, Xu D, Li Y, Li C, Peng L, Li Y, Xie W, Cui D, Shang L, Fan G, Xu J, Wang G, Wang Y, Zhong J, Wang C, Wang J, Zhang D, Cao B. 6-month consequences of COVID-19 in patients discharged from hospital: a cohort study. Lancet. 2021 Jan 16;397(10270):220-232. doi: 10.1016/S0140-6736(20)32656-8.

6- Callard F, Perego E. How and why patients made Long COVID. Soc Sci Med. 2021 Jan;268:113426. doi: 10.1016/j.socscimed.2020.113426. Epub 2020 Oct 7. PMID: 33199035; PMCID: PMC7539940.

7- https://www.euro.who.int/en/health-topics/healthemergencies/pages/news/news/2021/02/new-policy-brief-calls-on-decisionmakers-to-support-patients-as-1-in-10-report-symptoms-of-longCOVID/understanding-and-managing-long-COVID-requires-a-patient-led-approach

8- Ludvigsson JF. Case report and systematic review suggest that children may experience similar long-term effects to adults after clinical COVID-19. Acta Paediatr. 2021 Mar;110(3):914-921. doi: 10.1111/apa.15673 
9- Buonsenso D, Munblit D, De Rose C, Sinatti D, Ricchiuto A, Carfi A, Valentini P. Preliminary Evidence on Long COVID in children. medRxiv 2021.01.23.21250375; doi:https://doi.org/10.1101/2021.01.23.21250375

10-Buonsenso D, Roland D, De Rose C, Vásquez-Hoyos P, Ramly B, Chakakala-Chaziya JN, Munro A, González-Dambrauskas S. SCHOOLS CLOSURES DURING THE COVID-19 PANDEMIC: A Catastrophic Global Situation. Pediatr Infect Dis J. 2021 Jan 12. doi: 10.1097/INF.0000000000003052.

11-Lavigne-Cerván R, Costa-López B, Juárez-Ruiz de Mier R, Real-Fernández M, SánchezMuñoz de León M, Navarro-Soria I. Consequences of COVID-19 Confinement on Anxiety, Sleep and Executive Functions of Children and Adolescents in Spain. Front Psychol. 2021 Feb 16;12:565516. doi: 10.3389/fpsyg.2021.565516.

12-Buonsenso D, De Rose C, Mariotti P. Children experienced new or worsening tic issues when they were separated from their parents during the Italian COVID-19 lockdown. Acta Paediatr. 2021 Feb;110(2):394-396. doi: 10.1111/apa.15684. Epub 2020 Dec 4. PMID: 33220076; PMCID: PMC7753505.

13- Bressan S, Buonsenso D, Farrugia R, Parri N, Oostenbrink R, Titomanlio L, Roland D, Nijman RG, Maconochie I, Da Dalt L, Mintegi S; Country Leads. Preparedness and Response to Pediatric COVID-19 in European Emergency Departments: A Survey of the REPEM and PERUKI Networks. Ann Emerg Med. 2020 Dec;76(6):788-800. doi: 10.1016/j.annemergmed.2020.05.018. Epub 2020 May 15. PMID: 32419713; PMCID: PMC7225691. 


\section{Appendix}

Table A1. Pre-existing conditions before COVID-19 infection (multiple choices and free text allowed). Conditions found only in 1 Long-COVID child were grouped into Other

\begin{tabular}{|c|c|c|}
\hline Precondition & Freq & $\%$ \\
\hline Abdominal migraines & 2 & $0.4 \%$ \\
\hline ADHD/ADS & 28 & $5.5 \%$ \\
\hline Allergies & 81 & $15.9 \%$ \\
\hline Anxiety & 38 & $7.5 \%$ \\
\hline Asthma & 74 & $14.5 \%$ \\
\hline Autism & 29 & $5.7 \%$ \\
\hline Cerebral Palsy & 2 & $0.4 \%$ \\
\hline Coeliac & 8 & $1.6 \%$ \\
\hline Downs Syndrome & 3 & $0.6 \%$ \\
\hline Dyspraxia & 6 & $1.2 \%$ \\
\hline Eczema & 63 & $12.4 \%$ \\
\hline EDS & 6 & $1.2 \%$ \\
\hline Epilepsy & 9 & $1.8 \%$ \\
\hline Epstein Bar & 6 & $1.2 \%$ \\
\hline Gluten sensitivity & 2 & $0.4 \%$ \\
\hline Hayfever & 2 & $0.4 \%$ \\
\hline Headaches & 36 & $7.1 \%$ \\
\hline Heart disease & 2 & $0.4 \%$ \\
\hline Heart murmur & 2 & $0.4 \%$ \\
\hline HPV Virus & 2 & $0.4 \%$ \\
\hline HSV virus & 2 & $0.4 \%$ \\
\hline Hyper-mobility & 51 & $10 \%$ \\
\hline Hypertonia & 5 & $1 \%$ \\
\hline IBS & 4 & $0.8 \%$ \\
\hline Lyme Disease & 3 & $0.6 \%$ \\
\hline OCD/Depression/Anxiety & 36 & $7.1 \%$ \\
\hline Pandas & 2 & $0.4 \%$ \\
\hline POT's & 6 & $1.2 \%$ \\
\hline Sensory Processing Disorder & 4 & $0.8 \%$ \\
\hline Stomach pain & 2 & $0.4 \%$ \\
\hline TICS/Tourettes & 3 & $0.6 \%$ \\
\hline Urticaria & 2 & $0.4 \%$ \\
\hline Other & 48 & $9.4 \%$ \\
\hline None & 223 & $43.7 \%$ \\
\hline
\end{tabular}


Table A2. Symptoms present since COVID-19 infection (multiple choices allowed), by confirmation status of COVID-19 infection.

\begin{tabular}{|c|c|c|c|c|}
\hline Symptom & All & $\begin{array}{l}\text { Clinical } \\
\text { Diagnosis }\end{array}$ & $\begin{array}{l}\text { Positive } \\
\text { Test }\end{array}$ & $\begin{array}{l}\text { Unconfirmed } \\
\text { but Suspected }\end{array}$ \\
\hline \multicolumn{5}{|l|}{ Cardio-respiratory } \\
\hline Heart palpitations & $205(40.2 \%)$ & $71(45.5 \%)$ & $61(42.1 \%)$ & $73(34.9 \%)$ \\
\hline Coughing & $151(29.6 \%)$ & $52(33.3 \%)$ & $43(29.7 \%)$ & $56(26.8 \%)$ \\
\hline Throat clearing & $107(21 \%)$ & $30(19.2 \%)$ & $30(20.7 \%)$ & $47(22.5 \%)$ \\
\hline \multicolumn{5}{|l|}{ Dermatologic } \\
\hline A rash & 267 (52.4\%) & $83(53.2 \%)$ & $73(50.3 \%)$ & $111(53.1 \%)$ \\
\hline Red and cracked lips & $201(39.4 \%)$ & $69(44.2 \%)$ & $53(36.6 \%)$ & 79 (37.8\%) \\
\hline $\begin{array}{l}\text { Peeling skin on your hands and } \\
\text { feet }\end{array}$ & $143(28 \%)$ & $52(33.3 \%)$ & $37(25.5 \%)$ & $54(25.8 \%)$ \\
\hline Swollen hands and feet & 107 (21\%) & $43(27.6 \%)$ & $24(16.6 \%)$ & 40 (19.1\%) \\
\hline Ulcers & $79(15.5 \%)$ & $24(15.4 \%)$ & $17(11.7 \%)$ & $38(18.2 \%)$ \\
\hline \multicolumn{5}{|l|}{ Gastrointestinal } \\
\hline Tummy pain or cramps & 387 (75.9\%) & $\begin{array}{r}124 \\
(79.5 \%)\end{array}$ & $\begin{array}{r}111 \\
(76.6 \%)\end{array}$ & $152(72.7 \%)$ \\
\hline Nausea & $233(45.7 \%)$ & $80(51.3 \%)$ & $67(46.2 \%)$ & $86(41.1 \%)$ \\
\hline Diarrhea and vomiting & $216(42.4 \%)$ & $78(50 \%)$ & $67(46.2 \%)$ & $71(34 \%)$ \\
\hline \multicolumn{5}{|l|}{$\begin{array}{l}\text { HEENT (Head, ears, eyes, nose, } \\
\text { throat) }\end{array}$} \\
\hline Red eyes & $206(40.4 \%)$ & $74(47.4 \%)$ & 55 (37.9\%) & $77(36.8 \%)$ \\
\hline Sore throat & $230(45.1 \%)$ & $80(51.3 \%)$ & $60(41.4 \%)$ & 90 (43.1\%) \\
\hline Swollen neck glands & $128(25.1 \%)$ & 49 (31.4\%) & $36(24.8 \%)$ & $43(20.6 \%)$ \\
\hline \multicolumn{5}{|l|}{ Musculoskeletal } \\
\hline Muscle aches and pains & $349(68.4 \%)$ & 117 (75\%) & $\begin{array}{r}102 \\
(70.3 \%)\end{array}$ & $130(62.2 \%)$ \\
\hline Muscle and joint pain & $309(60.6 \%)$ & $103(66 \%)$ & $92(63.4 \%)$ & $114(54.5 \%)$ \\
\hline \multicolumn{5}{|l|}{ Neurological } \\
\hline Headache & $401(78.6 \%)$ & $131(84 \%)$ & $116(80 \%)$ & $154(73.7 \%)$ \\
\hline Unexplained irritability & 262 (51.4\%) & $90(57.7 \%)$ & $70(48.3 \%)$ & $102(48.8 \%)$ \\
\hline Dizzyness & $245(48 \%)$ & $82(52.6 \%)$ & 77 (53.1\%) & $86(41.1 \%)$ \\
\hline Twitches & 55 (10.8\%) & 17 (10.9\%) & $16(11 \%)$ & $22(10.5 \%)$ \\
\hline Word repetition & $52(10.2 \%)$ & $20(12.8 \%)$ & $16(11 \%)$ & $16(7.7 \%)$ \\
\hline Tics & $47(9.2 \%)$ & $18(11.5 \%)$ & $8(5.5 \%)$ & $21(10 \%)$ \\
\hline
\end{tabular}




$\begin{array}{lrrrr}\text { Stuttering } & 40(7.8 \%) & 11(7.1 \%) & 10(6.9 \%) & 19(9.1 \%) \\ \text { Swearing } & 26(5.1 \%) & 11(7.1 \%) & 4(2.8 \%) & 11(5.3 \%) \\ \text { Growling } & 24(4.7 \%) & 9(5.8 \%) & 6(4.1 \%) & 9(4.3 \%) \\ \text { General } & & & \\ \text { Tiredness and weakness } & 444(87.1 \%) & 139 & 131 & 174(83.3 \%) \\ & & (89.1 \%) & (90.3 \%) & 155(74.2 \%) \\ \text { Fatigue } & 410(80.4 \%) & 139 & 116(80 \%) & \\ & & (89.1 \%) & & \\ \text { Post-exertional malaise } & 274(53.7 \%) & 110 & 71(49 \%) & \\ & 151(29.6 \%) & 63(40.4 \%) & 45(31 \%) & 43(20.6 \%) \\ \text { Fever } & 121(23.7 \%) & 49(31.4 \%) & 37(25.5 \%) & 35(16.7 \%) \\ \text { Flu-like symptoms } & & (70.5 \%) & \\ \text { Other } & 7(1.4 \%) & 2(1.3 \%) & 1(0.7 \%) & 4(1.9 \%) \\ \text { Sepsis } & 7(1.4 \%) & 2(1.3 \%) & 1(0.7 \%) & 4(1.9 \%) \\ \text { Appendicitis } & 1(0.2 \%) & 1(0.6 \%) & 0(0 \%) & 0(0 \%) \\ \text { Peritonitis } & & & \end{array}$

Table A3. Changes reported since COVID infection, by confirmation status of COVID-19 infection, and by the pre-existence of comorbidity conditions

\begin{tabular}{|c|c|c|c|c|c|c|}
\hline $\begin{array}{l}\text { Changed since } \\
\text { COVID }\end{array}$ & All & $\begin{array}{l}\text { Clinical } \\
\text { Diagnosis }\end{array}$ & $\begin{array}{l}\text { Positive } \\
\text { Test }\end{array}$ & $\begin{array}{l}\text { Unconfirmed } \\
\text { but Suspected }\end{array}$ & $\begin{array}{l}\text { Had Pre- } \\
\text { conditions }\end{array}$ & $\begin{array}{l}\text { No Pre- } \\
\text { conditions }\end{array}$ \\
\hline Appetite & $253(49.6 \%)$ & $93(59.6 \%)$ & $72(49.7 \%)$ & $88(42.1 \%)$ & $146(50.9 \%)$ & $107(48 \%)$ \\
\hline Behaviour & $166(32.5 \%)$ & $46(29.5 \%)$ & $40(27.6 \%)$ & $80(38.3 \%)$ & $91(31.7 \%)$ & $75(33.6 \%)$ \\
\hline Cognitive function & 197 (38.6\%) & 75 (48.1\%) & $56(38.6 \%)$ & $66(31.6 \%)$ & $126(43.9 \%)$ & $71(31.8 \%)$ \\
\hline Energy levels & 425 (83.3\%) & 137 (87.8\%) & 127 (87.6\%) & $161(77 \%)$ & $241(84 \%)$ & $\begin{array}{r}184 \\
(82.5 \%)\end{array}$ \\
\hline Eye sight & $110(21.6 \%)$ & $39(25 \%)$ & $25(17.2 \%)$ & $46(22 \%)$ & $63(22 \%)$ & 47 (21.1\%) \\
\hline Hearing & $36(7.1 \%)$ & $15(9.6 \%)$ & $4(2.8 \%)$ & $17(8.1 \%)$ & $18(6.3 \%)$ & $18(8.1 \%)$ \\
\hline Mental health & $188(36.9 \%)$ & $56(35.9 \%)$ & $60(41.4 \%)$ & $72(34.4 \%)$ & 115 (40.1\%) & $73(32.7 \%)$ \\
\hline Mobility & 187 (36.7\%) & $70(44.9 \%)$ & $50(34.5 \%)$ & $67(32.1 \%)$ & 113 (39.4\%) & $74(33.2 \%)$ \\
\hline Mood & 300 (58.8\%) & $89(57.1 \%)$ & 87 (60\%) & $124(59.3 \%)$ & $173(60.3 \%)$ & $127(57 \%)$ \\
\hline Skin & $189(37.1 \%)$ & $64(41 \%)$ & 47 (32.4\%) & $78(37.3 \%)$ & $109(38 \%)$ & $80(35.9 \%)$ \\
\hline Sleep & $287(56.3 \%)$ & $95(60.9 \%)$ & $91(62.8 \%)$ & $101(48.3 \%)$ & $164(57.1 \%)$ & $\begin{array}{r}123 \\
(55.2 \%)\end{array}$ \\
\hline Toilet habits & $124(24.3 \%)$ & $45(28.8 \%)$ & $32(22.1 \%)$ & 47 (22.5\%) & $67(23.3 \%)$ & $57(25.6 \%)$ \\
\hline
\end{tabular}


Table A4. Number of changes since COVID-19 infection, by confirmation status of infection, and by the pre-existence of comorbidity conditions

\begin{tabular}{lrrlrlr}
$\begin{array}{l}\text { Number of } \\
\text { changes since } \\
\text { CoVID-19 }\end{array}$ & \multicolumn{1}{c}{ All } & $\begin{array}{l}\text { Clinical } \\
\text { Diagnosis }\end{array}$ & $\begin{array}{l}\text { Positive } \\
\text { Test }\end{array}$ & $\begin{array}{l}\text { Unconfirmed } \\
\text { but } \\
\text { suspected }\end{array}$ & $\begin{array}{l}\text { lad Pre- } \\
\text { Conditions }\end{array}$ & \multicolumn{1}{l}{$\begin{array}{l}\text { No Pre- } \\
\text { Conditions }\end{array}$} \\
\hline $\mathbf{1}$ & $63(12.4 \%)$ & $16(10.3 \%)$ & $15(10.3 \%)$ & $32(15.3 \%)$ & $31(10.8 \%)$ & $32(14.3 \%)$ \\
$\mathbf{2}$ & $59(11.6 \%)$ & $15(9.6 \%)$ & $17(11.7 \%)$ & $27(12.9 \%)$ & $31(10.8 \%)$ & $28(12.6 \%)$ \\
$\mathbf{3}$ & $63(12.4 \%)$ & $20(12.8 \%)$ & $17(11.7 \%)$ & $26(12.4 \%)$ & $38(13.2 \%)$ & $25(11.2 \%)$ \\
$\mathbf{4}$ or more & $325(63.7 \%)$ & $105(67.3 \%)$ & $96(66.2 \%)$ & $124(59.3 \%)$ & 187 & $138(61.9 \%)$
\end{tabular}

Table A5. Activity level before infection by Participation in Any level of activity in the first 6 weeks of COVID-19 infection

\begin{tabular}{lrrrr} 
Activity before infection & \multicolumn{4}{c}{ Activity first 6 weeks } \\
\hline & No & Unsure & Yes & Total \\
\hline Daily Sports/Dance & 44 & 4 & 96 & 144 \\
Weekly Sports/Dance & 77 & 10 & 92 & 179 \\
Weekly Moderate & 76 & 13 & 71 & 160 \\
Activity & & & & \\
Very Occasional Activity & 13 & 4 & 1 & 18 \\
Rare Activity & 7 & 0 & 2 & 9
\end{tabular}

Table A6. Child's current activity level by Activity level before infection

Current Activity

\begin{tabular}{|c|c|c|c|c|c|c|}
\hline & $\begin{array}{r}\text { Daily } \\
\text { Sports/Dance }\end{array}$ & $\begin{array}{r}\text { Weekly } \\
\text { Sports/Dance }\end{array}$ & $\begin{array}{r}\text { Weekly } \\
\text { Moderate }\end{array}$ & $\begin{array}{r}\text { Very } \\
\text { Occasional }\end{array}$ & $\begin{array}{r}\text { Rare } \\
\text { Activity }\end{array}$ & Total \\
\hline $\begin{array}{l}\text { Returned to } \\
\text { previous }\end{array}$ & 17 & 15 & 18 & 1 & 0 & 51 \\
\hline Level varies by day & 38 & 59 & 58 & 6 & 4 & 165 \\
\hline $\begin{array}{l}\text { Occasional, same } \\
\text { symptoms }\end{array}$ & 10 & 9 & 9 & 4 & 0 & 32 \\
\hline $\begin{array}{l}\text { Occasional, worst } \\
\text { symptoms }\end{array}$ & 44 & 59 & 46 & 2 & 3 & 154 \\
\hline Unable to enjoy & 35 & 37 & 29 & 5 & 2 & 108 \\
\hline
\end{tabular}


Table A7. Mental health / cognitive issues since COVID-19 infection (multiple issues per child are usual), by confirmation status of infection, and by the pre-existence of comorbidity conditions

\begin{tabular}{|c|c|c|c|c|c|c|}
\hline Mental Health / Cognitive Issues & All & $\begin{array}{l}\text { Clinical } \\
\text { Diagnosis }\end{array}$ & $\begin{array}{l}\text { Positive } \\
\text { Test }\end{array}$ & $\begin{array}{l}\text { Unconfirmed } \\
\text { but } \\
\text { Suspected }\end{array}$ & $\begin{array}{l}\text { Had Pre- } \\
\text { conditions }\end{array}$ & $\begin{array}{l}\text { No Pre- } \\
\text { conditions }\end{array}$ \\
\hline Difficulty in doing everyday tasks & 204 (40\%) & 79 (50.6\%) & $61(42.1 \%)$ & $64(30.6 \%)$ & $122(42.5 \%)$ & $82(36.8 \%)$ \\
\hline Difficulty processing information & $\begin{array}{r}167 \\
(32.7 \%)\end{array}$ & $62(39.7 \%)$ & $49(33.8 \%)$ & 56 (26.8\%) & $110(38.3 \%)$ & $57(25.6 \%)$ \\
\hline $\begin{array}{l}\text { Difficulty remembering } \\
\text { information }\end{array}$ & $\begin{array}{r}234 \\
(45.9 \%)\end{array}$ & $88(56.4 \%)$ & $66(45.5 \%)$ & $80(38.3 \%)$ & $140(48.8 \%)$ & $94(42.2 \%)$ \\
\hline $\begin{array}{l}\text { Difficulty understanding } \\
\text { instruction }\end{array}$ & $\begin{array}{r}147 \\
(28.8 \%)\end{array}$ & $57(36.5 \%)$ & $35(24.1 \%)$ & $55(26.3 \%)$ & $86(30 \%)$ & $61(27.4 \%)$ \\
\hline Finds it difficult to make a decision & $\begin{array}{r}139 \\
(27.3 \%)\end{array}$ & $46(29.5 \%)$ & $38(26.2 \%)$ & 55 (26.3\%) & $81(28.2 \%)$ & $58(26 \%)$ \\
\hline $\begin{array}{l}\text { Finds it hard to work out what } \\
\text { order to do things in }\end{array}$ & $89(17.5 \%)$ & $30(19.2 \%)$ & $28(19.3 \%)$ & $31(14.8 \%)$ & $55(19.2 \%)$ & $34(15.2 \%)$ \\
\hline Forgets what they are saying & $\begin{array}{r}146 \\
(28.6 \%)\end{array}$ & $54(34.6 \%)$ & $46(31.7 \%)$ & $46(22 \%)$ & $91(31.7 \%)$ & $55(24.7 \%)$ \\
\hline $\begin{array}{l}\text { Hesitating before speaking or } \\
\text { moving }\end{array}$ & $102(20 \%)$ & $34(21.8 \%)$ & $32(22.1 \%)$ & $36(17.2 \%)$ & $58(20.2 \%)$ & 44 (19.7\%) \\
\hline Lack of concentration & $\begin{array}{r}309 \\
(60.6 \%)\end{array}$ & $\begin{array}{r}108 \\
(69.2 \%)\end{array}$ & 89 (61.4\%) & $112(53.6 \%)$ & $180(62.7 \%)$ & 129 (57.8\%) \\
\hline Often has a vacant look & $107(21 \%)$ & $31(19.9 \%)$ & $44(30.3 \%)$ & $32(15.3 \%)$ & $67(23.3 \%)$ & 40 (17.9\%) \\
\hline Short term memory issues & $\begin{array}{r}167 \\
(32.7 \%)\end{array}$ & $66(42.3 \%)$ & $47(32.4 \%)$ & $54(25.8 \%)$ & $108(37.6 \%)$ & $59(26.5 \%)$ \\
\hline $\begin{array}{l}\text { Struggles to choose appropriate } \\
\text { clothes }\end{array}$ & $54(10.6 \%)$ & $16(10.3 \%)$ & $16(11 \%)$ & $22(10.5 \%)$ & $31(10.8 \%)$ & $23(10.3 \%)$ \\
\hline Struggles to find the right words & $\begin{array}{r}162 \\
(31.8 \%)\end{array}$ & $65(41.7 \%)$ & $41(28.3 \%)$ & $56(26.8 \%)$ & 95 (33.1\%) & $67(30 \%)$ \\
\hline Stuttering & $40(7.8 \%)$ & $9(5.8 \%)$ & $14(9.7 \%)$ & 17 (8.1\%) & $19(6.6 \%)$ & $21(9.4 \%)$ \\
\hline $\begin{array}{l}\text { Uses the wrong words for people } \\
\text { or objects }\end{array}$ & $73(14.3 \%)$ & $26(16.7 \%)$ & $21(14.5 \%)$ & $26(12.4 \%)$ & $45(15.7 \%)$ & $28(12.6 \%)$ \\
\hline None of the above & $\begin{array}{r}111 \\
(21.8 \%)\end{array}$ & 24 (15.4\%) & $29(20 \%)$ & $58(27.8 \%)$ & $57(19.9 \%)$ & $54(24.2 \%)$ \\
\hline Other & 53 (10.4\%) & $18(11.5 \%)$ & $11(7.6 \%)$ & 24 (11.5\%) & 33 (11.5\%) & $20(9 \%)$ \\
\hline
\end{tabular}


Table A8. Number of mental health / cognitive issues since COVID-19 infection (from those in Table 5, excluding "None of the above" and "Other"), by confirmation status of infection, and by the pre-existence of comorbidity conditions

\begin{tabular}{lrllrrr}
$\begin{array}{l}\text { Number of } \\
\text { issues since } \\
\text { COVID-19 }\end{array}$ & \multicolumn{1}{c}{ All } & $\begin{array}{l}\text { Clinical } \\
\text { Diagnosis }\end{array}$ & \multicolumn{1}{l}{$\begin{array}{l}\text { Positive } \\
\text { Test }\end{array}$} & $\begin{array}{l}\text { Unconfirmed } \\
\text { but suspected }\end{array}$ & $\begin{array}{l}\text { Had Pre- } \\
\text { Conditions }\end{array}$ & $\begin{array}{l}\text { No Pre- } \\
\text { Conditions }\end{array}$ \\
\hline $\mathbf{0}$ & $132(25.9 \%)$ & $28(17.9 \%)$ & $32(22.1 \%)$ & $72(34.4 \%)$ & $68(23.7 \%)$ & $64(28.7 \%)$ \\
$\mathbf{1}$ & $54(10.6 \%)$ & $17(10.9 \%)$ & $18(12.4 \%)$ & $19(9.1 \%)$ & $29(10.1 \%)$ & $25(11.2 \%)$ \\
$\mathbf{2}$ & $45(8.8 \%)$ & $9(5.8 \%)$ & $12(8.3 \%)$ & $24(11.5 \%)$ & $18(6.3 \%)$ & $27(12.1 \%)$ \\
$\mathbf{3}$ or more & $279(54.7 \%)$ & $102(65.4 \%)$ & $83(57.2 \%)$ & $94(45 \%)$ & 172 & $107(48 \%)$
\end{tabular}

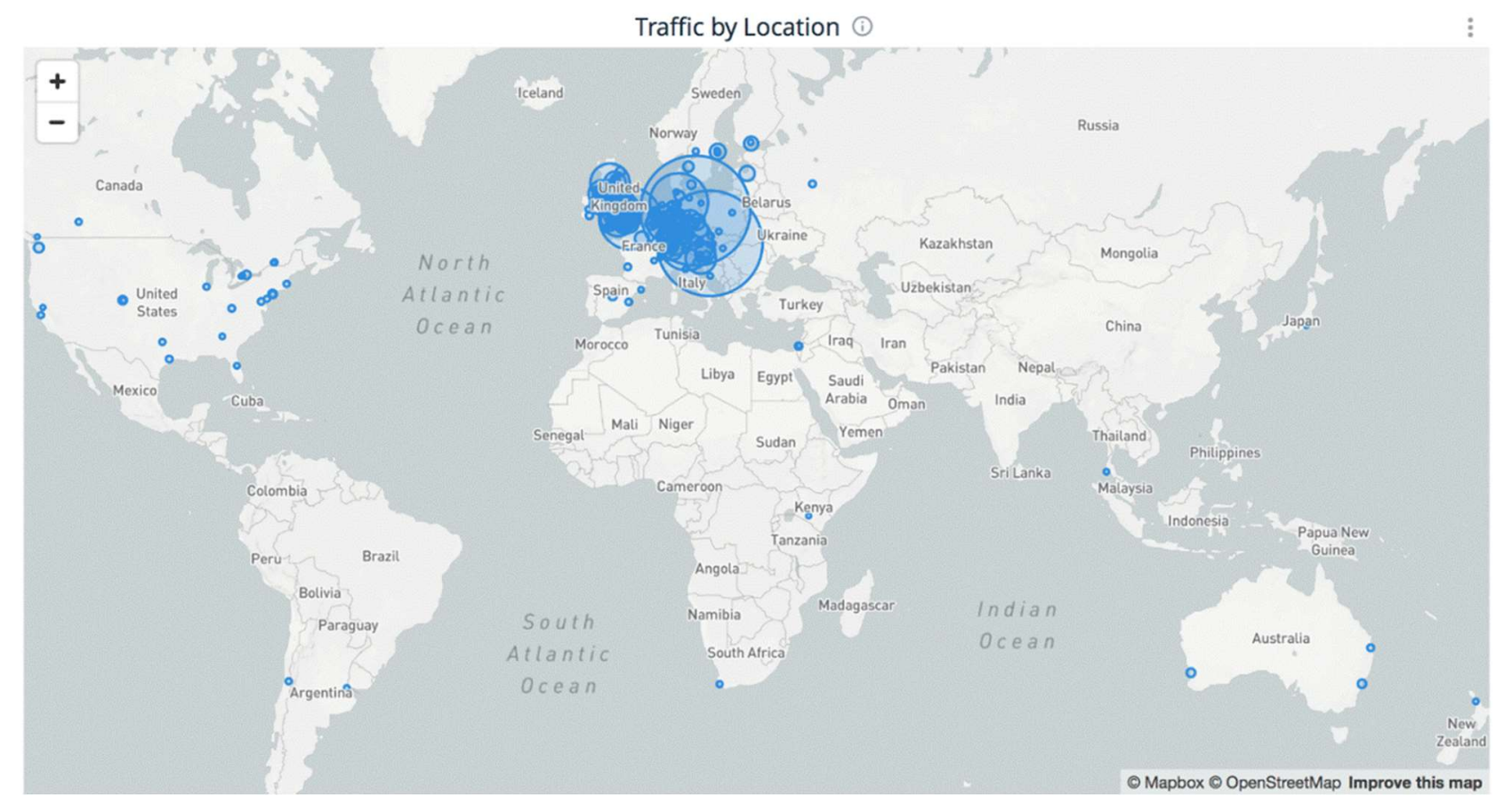




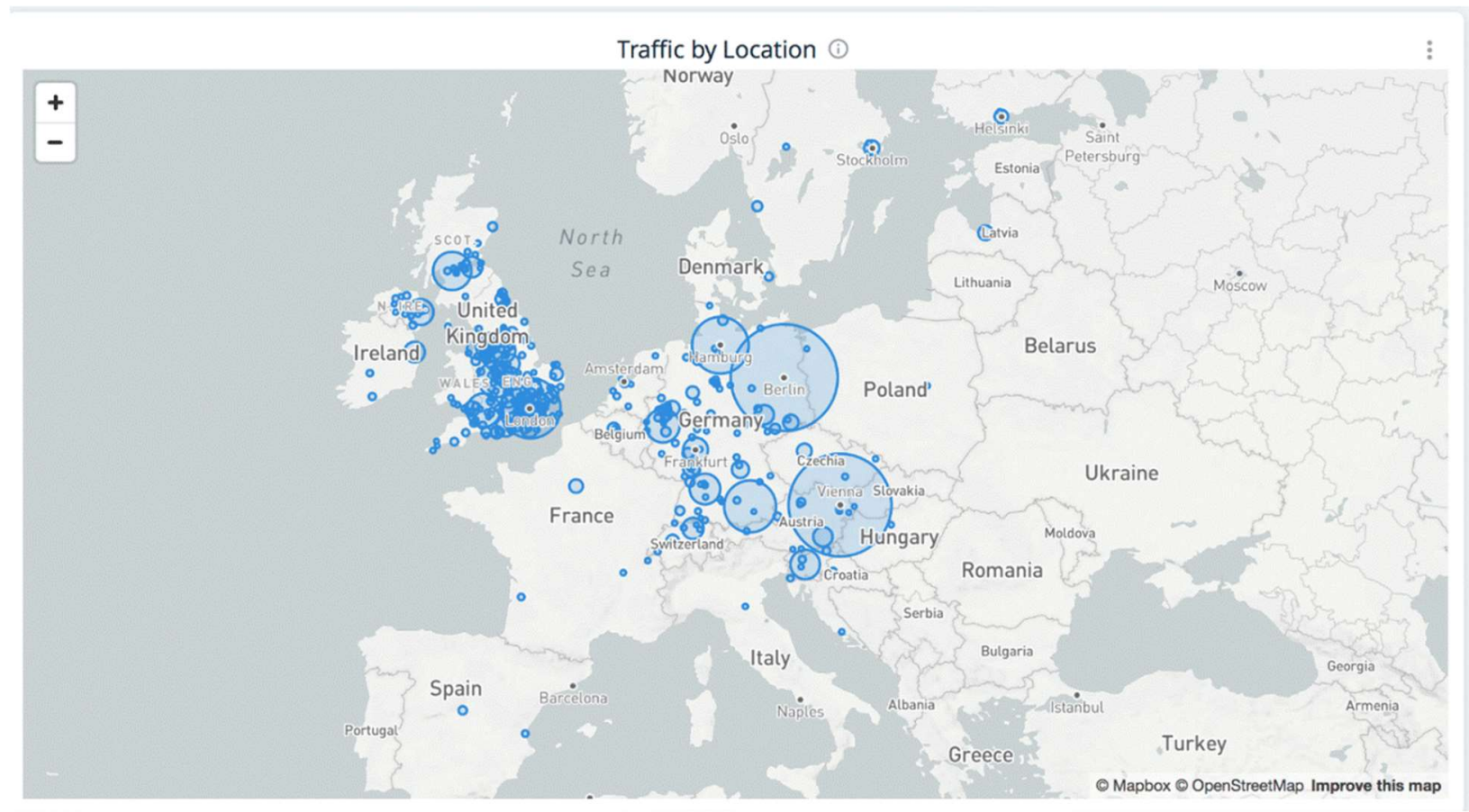

Appendix Figure A1. Social media traffic of the Long Covid Kids UK platform. 